The Power of Urban Water 



\section{The Power of Urban Water}

Studies in Premodern Urbanism

Edited by

Nicola Chiarenza, Annette Haug and Ulrich Müller 
The publication of this volume was funded by the Kieler Exzellenzcluster ROOTS - Social, Environmental, and Cultural Connectivity in Past Societies.

ISBN 978-3-11-067664-8

e-ISBN (PDF) 978-3-11-067706-5

e-ISBN (EPUB) 978-3-11-067712-6

DOI https://doi.org/10.1515/9783110677065

\section{(cc) BY-NC-ND}

This work is licensed under a Creative Commons Attribution-NonCommercial-NoDerivatives 4.0 International License. For details go to http://creativecommons.org/licenses/by-nc-nd/4.0/.

\section{Library of Congress Control Number: 2019955887}

Bibliographic information published by the Deutsche Nationalbibliothek The Deutsche Nationalbibliothek lists this publication in the Deutsche Nationalbibliografie; detailed bibliographic data are available on the Internet at http://dnb.dnb.de.

(c) 2020 Nicola Chiarenza, Annette Haug and Ulrich Müller. Published by Walter de Gruyter GmbH, Berlin/Boston Cover: G. Dalli Cani, Accademia di Belle Arti di Verona, 2000, with consultancy after Margherita Bolla Typesetting: Meta Systems Publishing \& Printservices GmbH, Wustermark Print and binding: $\mathrm{CPI}$ books $\mathrm{GmbH}$, Leck 